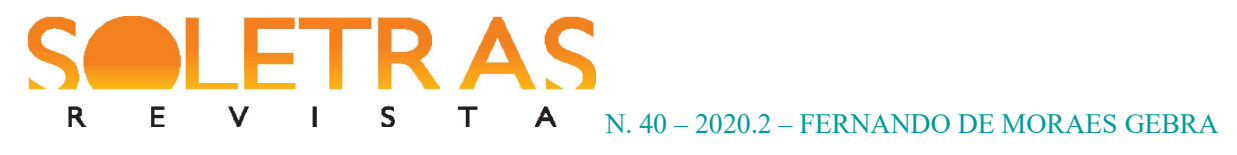

\title{
Orpheu e a imprensa no caderno de Alfredo Guisado: "Recortes" de uma revista literária
}

\author{
Fernando de Moraes Gebra ${ }^{1}$
}

\begin{abstract}
Resumo: Alfredo Guisado (1891-1975) organizou um caderno de recortes de imprensa sobre a revista Orpheu em 1915. Muitos desses textos coletados e arquivados no caderno de recortes foram publicados e comentados por Alfredo Guisado na sua página literária no jornal República, principalmente na década de 1960. O presente artigo examina esses textos onde se citam e se transcrevem integralmente recortes da imprensa portuguesa de 1915. A crítica literária, entendida como um gênero do discurso, responde a enunciados anteriores, estabelecendo com eles uma relação viva e tensa, conforme Mikhail Bakhtin. Analiso neste artigo o confronto entre três enunciações: a) o discurso da imprensa portuguesa em 1915 acerca da recepção de Orpheu; b) o discurso dos presencistas vistos como discurso de outrem no interior das enunciações de Alfredo Guisado na década de 1960; c) o discurso de Guisado, marcado por ironias, polêmica velada e até mesmo polêmica aberta. $\mathrm{O}$ autor tinha, pois, como objetivo esclarecer ao público como se pautavam os juízos da crítica de então e, ao mesmo tempo, responder a atitudes discursivas de membros da geração da revista Presença, que propagava no meio literário português a ideia de terem sido eles os grandes divulgadores dos textos dos de Orpheu.
\end{abstract}

Palavras-chave: Orpheu. Alfredo Guisado. República. Crítica literária. Recortes de imprensa.

\section{Introdução}

No dia 26 de março de 1915, numa sexta-feira, foi posta à venda a primeira tiragem de Orpheu, "revista trimestral de literatura", cujo primeiro número se destinava para os meses de janeiro, fevereiro e março. Esgotaram-se os exemplares, como destaca Fernando Pessoa em carta de 4 de abril a Armando Côrtes-Rodrigues, cogitando a possibilidade de se fazer uma segunda tiragem. Apesar do êxito de venda, a imprensa portuguesa fez comentários desfavoráveis aos escritores que acabaram por estabelecer um divisor de águas na Literatura portuguesa.

Na referida missiva a Côrtes-Rodrigues, Pessoa acrescenta que "Somos o assunto do dia em Lisboa. Sem exagero lho digo. O escândalo é enorme. Somos apontados na rua, e toda a gente - mesmo extraliterária - fala no Orpheu" (PESSOA, 1999a, p. 163). Em outra carta ao amigo açoriano e colaborador da empreitada órfica, datada de 19 de abril, Pessoa revela uma

\footnotetext{
${ }^{1}$ Doutor em Letras (área de Estudos Literários) pela Universidade Federal do Paraná (2009); tem experiência na área de Letras com ênfase em Literaturas de Língua Portuguesa. Brasil. E-mail: fernandogebra@yahoo.fr
} 


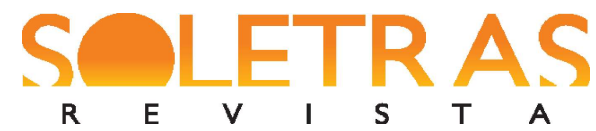

N. 40 - 2020.2 - FERNANDO DE MORAES GEBRA

atitude de escárnio diante dos artigos que a imprensa escreveu sobre Orpheu: "E não tenho tempo para tratar de reunir alguns, pelo menos, dos artigos que se têm escrito sobre o Orpheu, tenho pena de que não o possa fazer, porque v. havia de rir imenso com eles." (1999, p.164).

Se Fernando Pessoa e Côrtes-Rodrigues não puderam se dedicar a essa missão, Mário de Sá-Carneiro e Alfredo Guisado tiveram o cuidado de reunir, cada um à sua maneira, uma quantidade significativa de artigos em cadernos de recortes. Sobre a colecção de recortes de Sá-Carneiro já muito se escreveu. Os dois cadernos de recortes de do poeta, arquivados na Biblioteca Nacional de Portugal, apresentam 90 recortes de 31 jornais, “[...] apenas uma parte de tudo o que se apareceu na imprensa publicada em 35 localidades” (BLANCO, 2016, p. 82). Maria João Marques Covas elenca no seu trabalho 84 jornais e revistas, "[...] alertando para o facto de a lista que apresenta não ser exaustiva" (BLANCO, 2016, p. 82).

O único texto que examina o caderno de Alfredo Guisado é o de Patrícia Silva, publicado antes de o acervo do arquiteto Fernando Távora ser catalogado, certamente por indicação de Arnaldo Saraiva que já dera à estampa a correspondência de Sá-Carneiro a Alfredo Guisado, Luís de Montalvor, Cândida Ramos e José Pacheco, bem como outros textos que ainda não se encontravam para consulta a demais investigadores. Conforme Silva,

\begin{abstract}
Além de oferecer evidência documental valiosa acerca do material e da história cultural de Orpheu, os cadernos de recortes de imprensa sobre as recensões críticas da revista, guardados por Guisado e existentes no arquivo de Távora, desafiam a noção recebida de que Guisado rompeu definitivamente com o grupo depois do escândalo que se seguiu à publicação do primeiro número, fornecendo evidência conclusiva de que ele seguiu atentamente o progresso da revista na imprensa e na esfera pública geral por pelo menos algum tempo, de maneira privada. (SILVA, 2017, p. 331) ${ }^{2}$
\end{abstract}

De qualquer modo, convém ressaltar que, embora centrado mais nos recortes acerca do primeiro número da revista - certamente por não ter participado do segundo número -

\footnotetext{
${ }^{2}$ Aside from offering valuable documental evidence towards the material and cultural history of Orpheu, the notebooks of press cuttings of reviews of the magazine kept by Guisado and extant in the Távora archive challenge the received notion that he broke away from the group entirely after the scandal that followed the publication of the first issue, providing conclusive evidence that he attentively followed its progress in the press and the general public sphere for at least some time, if privately.
} 
Alfredo Guisado reuniu uma quantidade significativa de 32 textos publicados em jornais lisboetas, portuenses, algarvios, alentejanos e galegos.

Os recortes de imprensa encontram-se em um caderno de capa preta com a identificação "Críticas do Orfeu", arquivado na Fundação Engenheiro Marques da Silva. Se no caso da compilação de Sá-Carneiro, é possível distinguir um importante interesse documental para a história da revista literária, na de Alfredo Guisado, a documentação arquivada serviu de base a um projeto que começou a ser executado em 31 de dezembro de 1960, quando o então diretor-adjunto do jornal República passou a transcrever na sua página literária os textos arquivados em seu caderno, que fariam parte de um livro intitulado $O$ Orpheu por Dentro: história de uma revista literária, que nunca se concretizou.

\section{O Orpheu por Dentro}

A crítica literária, entendida como gênero do discurso, isto é, um tipo relativamente estável de enunciados, conforme a abordagem de Mikhail Bakhtin (2015a, p. 262), responde, como todo e qualquer discurso, a outros enunciados anteriores. No caso do discurso crítico de Alfredo Guisado, ao longo das páginas do jornal República, entre 1943 e 1972, seus textos ensaios literários com elementos memorialistas - reagem à tese do magistério que Pessoa teria exercido sobre os demais companheiros de Orpheu, formulada por Gaspar Simões e expressa no seu livro Vida e obra de Fernando Pessoa: História duma geração:

Bem certo que Mário de Sá-Carneiro o [a Pessoa] acompanhava - a sua "Manucure" o comprova - e que Alfredo Pedro Guisado, com os seus treze sonetos, escolar e metodicamente "paúlicos", o seguia de perto, outro tanto acontecendo com Armando Côrtes-Rodrigues, o qual, desobediente ao conselho que Pessoa the dera, lhe não enviara colaboração "interseccionista" (coisa explicável, de resto, pois a prática "interseccionista" pressupunha um virtuosismo intelectual, visual e analítico que Côrtes-Rodrigues estava longe de possuir), mas "paúlica", cem por cento "paúlica" [...] (SIMÕES, 1987, p. 217-8, destacados meus).

Muitos dos textos que Alfredo Guisado estampou na República, acerca de Orpheu, apresentam uma atitude responsiva ao discurso do grupo oriundo da revista Presença, que 


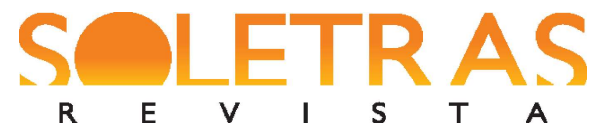

\section{N. 40 - 2020.2 - FERNANDO DE MORAES GEBRA}

propagava no meio literário português a ideia de terem sido eles os grandes divulgadores dos textos de Orpheu, que "[...] sem a Presença, Orfeu não teria sido nada, pois até os seus homens estariam, agora, em pleno esquecimento se ela não tivesse divulgado os seus nomes" (GUISADO, 18 jun. 1943, p. 7). É contra essa tese construída pelos próprios presencistas que Alfredo Guisado reage de maneira cáustica ao longo dos seus ensaios, a partir de recursos como insinuações, paródias, ironias, polêmica velada e até mesmo polêmica aberta.

Já aborrecido das invencionices de críticos literários como João Gaspar Simões e de outros posicionamentos segundo os quais Orpheu seria tributária da Presença e não o contrário, Alfredo Guisado decidiu, na década de 1960, organizar de maneira mais sistemática seus textos acerca da geração literária a que pertenceu. Em 4 de julho de 1960, em conversa prévia com Almada Negreiros, o projeto de escrever um livro intitulado O Orpheu por Dentro, com textos memorialísticos acerca dessa geração literária, é enunciado em carta a Armando Côrtes-Rodrigues.

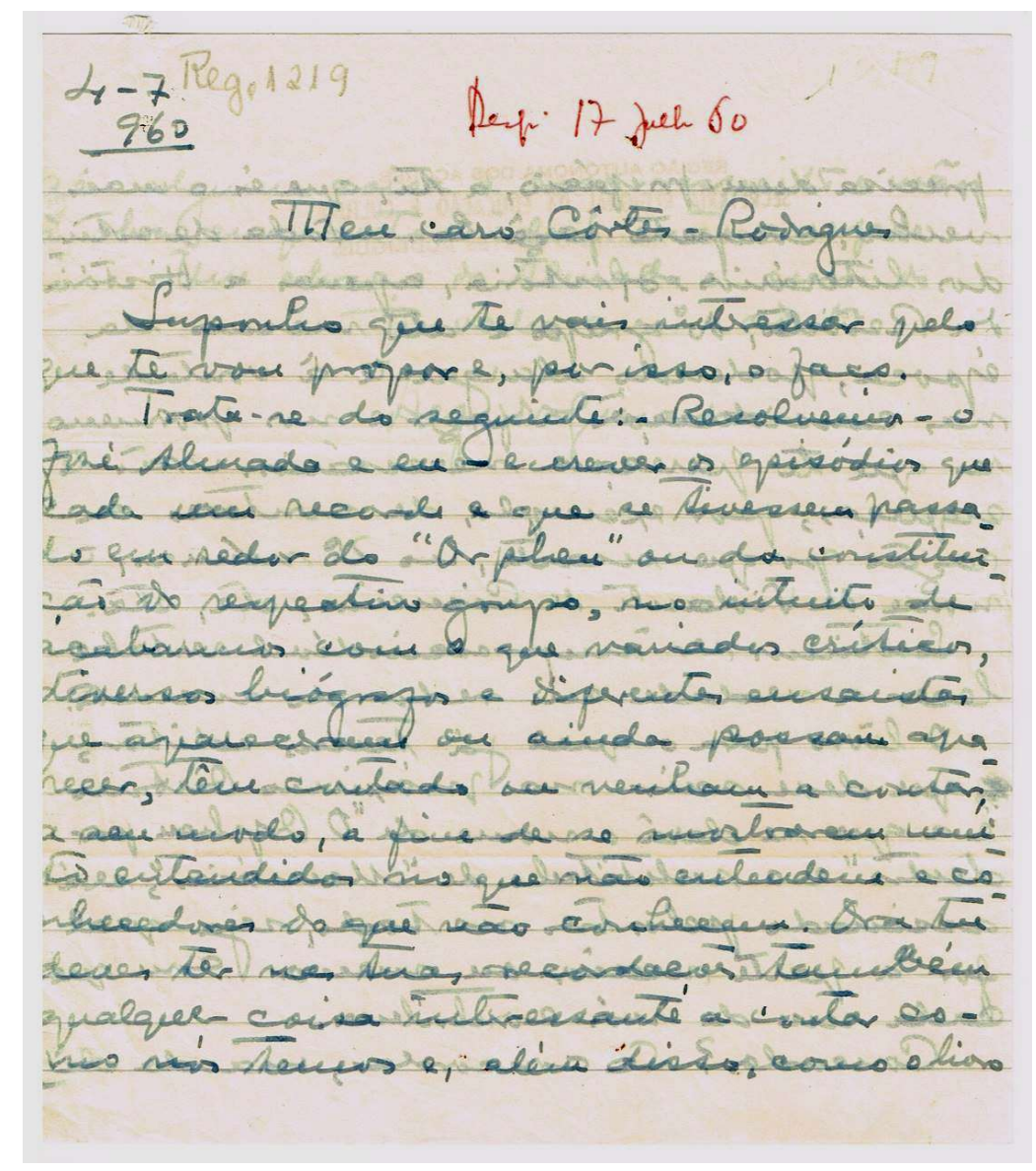



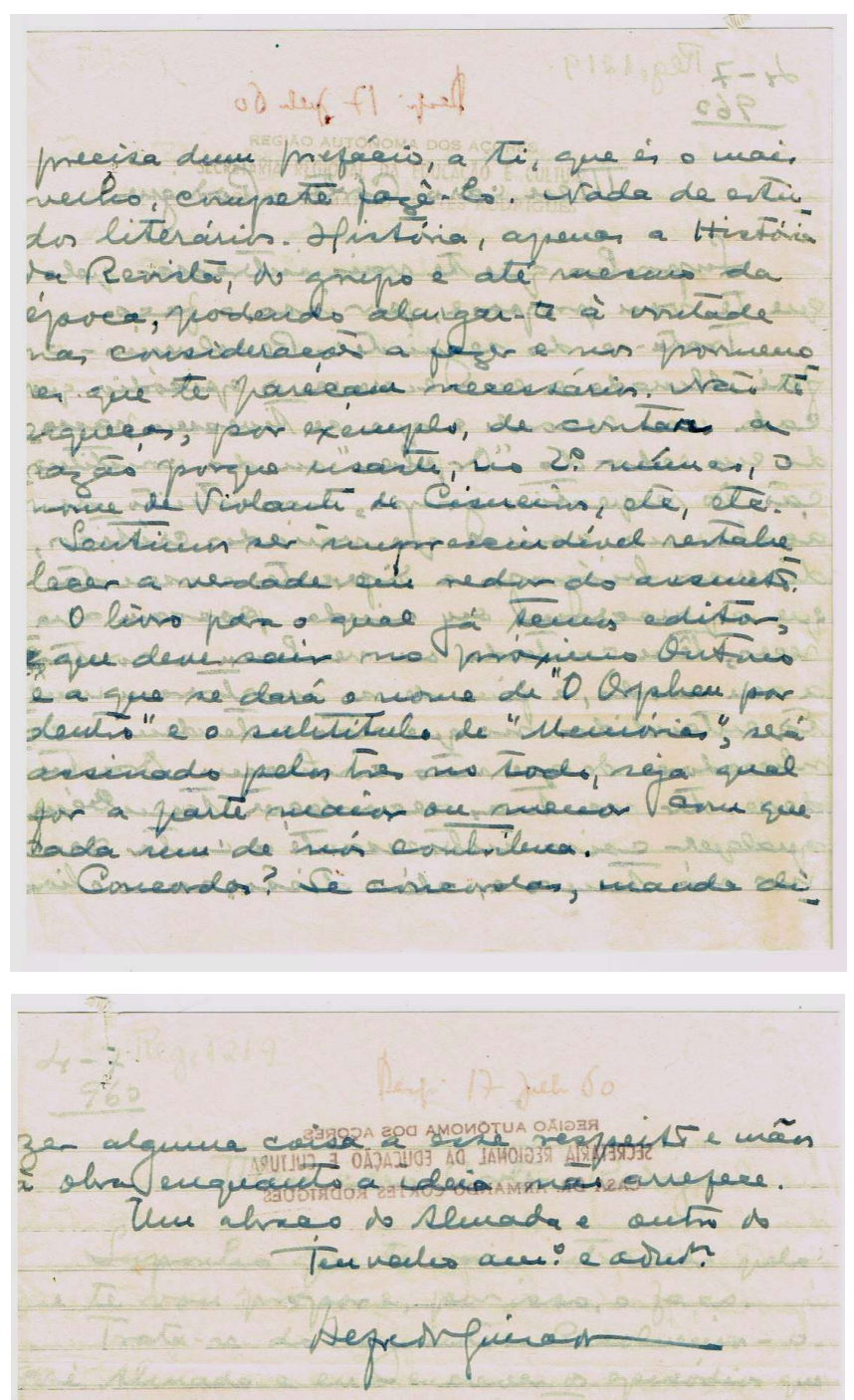

Fig.1 Carta de Alfredo Guisado a Armando Côrtes-Rodrigues, de 4 de julho de 1960. Fonte: Biblioteca Pública Arquivo Regional de Ponta Delgada, Acervo Côrtes-Rodrigues 1219

4 de Julho de 1960

Meu caro Côrtes-Rodrigues

Suponho que te vais interessar pelo que te vou propor e, por isso, o faço.

Trata-se do seguinte: - Resolvemos - o José Almada e eu - escrever os episódios que cada um recorde e que se tivessem passado em redor do Orpheu ou da constituição do respectivo grupo, no intuito de acabarmos com o que variados críticos, diversos biógrafos e diferentes ensaístas que apareceram ou ainda possam aparecer, têm contado ou venham a contar a seu modo, a fim de se mostrarem muito entendidos no que não entendem e conhecedores do que não conhecem. Ora tu deves ter nas tuas recordações qualquer coisa interessante a contar como nós temos e, além disso, como o livro precisa dum prefácio, a ti, que és o mais velho, compete fazê-lo. Nada 


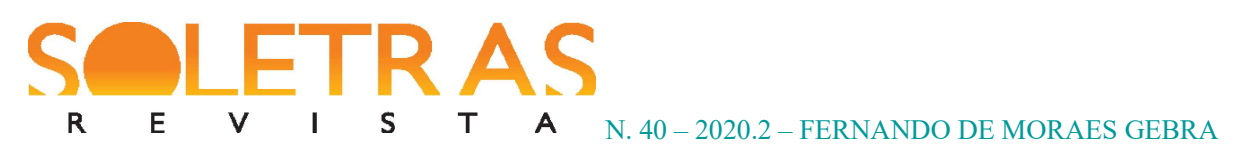

de estudos literários. História, apenas a História da Revista, do grupo e até mesmo da época, podendo alargar-te à vontade nas considerações a fazer e nos pormenores que te pareçam necessários. Não te esqueças, por exemplo, de contar a razão por que usaste, no $2^{\circ}$ número, o nome de Violante de Cisneiros, etc, etc.

Sentirmos ser imprescindível restabelecer a verdade em redor do assunto.

O livro para o qual já temos editor, que deve sair no próximo Outono e a que se dará o nome de "O Orpheu por dentro" e o subtítulo de "Memórias", será assinado pelos três no todo, seja qual for a parte maior ou menor com que cada um de nós contribua.

Concordas? Se concordas, manda dizer alguma coisa a esse respeito e mãos à obra enquanto a ideia não arrefece.

Um abraço do Almada e outro do

Do teu velho amigo e admirador.

Alfredo Guisado

O livro cujo subtítulo seria "Memórias" assinar-se-ia pelos sobreviventes do grupo de Orpheu naquela altura - Alfredo Guisado, Côrtes-Rodrigues e Almada Negreiros - entretanto, diante da impossibilidade da colaboração de seus companheiros, o escritor de Ânfora deixou nas páginas da República vários textos "do livro de memórias a sair em breve: O Orpheu por dentro" (GUISADO, 29 out. 1960, p. 5). Muitos desses textos constroem-se numa relação dialógica marcada por tensões com os discursos de Gaspar Simões e de outros críticos advindos da revista Presença, como Adolfo Casais Monteiro e José Régio.

A página literária que Alfredo Guisado dirigiu em República de 1943 a 1972 foi a arena onde seus enunciados digladiaram equívocos da crítica literária praticada por João Gaspar Simões, bem como as opiniões sarcásticas de jornais portugueses em 1915 que qualificavam as produções literárias dos artistas de Orpheu ora como sintomas de mentes alienadas ora como atitudes mistificadoras. Tem-se, pois, um conjunto significativo de 18 textos nos quais o autor transcreveu na íntegra os recortes de imprensa como A Capital, $O$ Mundo, O Século, O Jornal, O Século Cómico, A Montanha (Porto), O Povo, A Luta, A Nação e A Ilustração Portuguesa.

Além dos 18 textos nos quais efetivamente se transcreve na íntegra a maior parte dos recortes arquivados por Alfredo Guisado, destaco ainda, um significativo texto intitulado "Crítica literária”, no qual o autor “[...] verifica quanto, infelizmente, vale a crítica literária na nossa terra" (GUISADO, 13 out. 1961, p. 4). Dignas de nota são, igualmente, na década de 1940, duas importantes menções à recepção crítica da revista. A primeira encontra-se no 


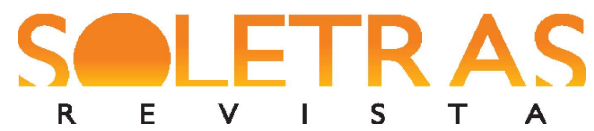

“Comentário", de 26 de março de 1943, na qual se transcrevem trechos do artigo "Literatura de manicómio", publicado em 30 de março de 1915 em A Capital. Já a segunda, revestida de maior importância uma vez que o discurso citado - a "Crónica Literária" que Fernando Pessoa publicara em $O$ Jornal em 6 de abril de 1915, e que se encontra arquivado na página 4 do caderno de recortes - , conduz à defesa de uma tese, data 12 de março de 1943. A partir da citação do texto de Fernando Pessoa, Guisado sedimenta as bases da tese que tanto defende ao longo das páginas de República, a de Orpheu ter dado origem a uma nova época literária.

A 28 anos de distância, os próprios inimigos são obrigados a reconhecer que a vitória do Orfeu foi completa, que, na nossa terra, se fez sentir a sua influência em todas as suas manifestações de Arte, que a alguns daqueles que foram escarnecidos já lhes foi prestada a devida justiça e que não tem faltado quem tenha querido continuar essa obra que aqueles homens iniciaram.

Orfeu quer queiram quer não, todos os que estavam acostumados a dizer segredos ao ouvido de qualquer "madame", marcou o início de uma nova época, de um novo ciclo na história da nossa literatura (GUISADO, 12 mar. 1943, p. 3).

Já naquela altura, quando assumiu a direção da página literária de República, Alfredo Guisado frisava que os oponentes do grupo de Orpheu tiveram de se lhe reconhecer a vitória. Ao transcrever a "Crónica Literária" de Fernando Pessoa, entende as palavras do seu companheiro de aventura órfica como dignas de serem arquivadas: "[...] que eu quero arquivar nessas colunas porque vale a pena reproduzi-las" (GUISADO, 12 mar. 1943, p. 3). A noção de arquivo faz-se, pois, presente no discurso ensaístico-memorialístico de Alfredo Guisado e assume o ponto de partida para a elaboração de uma hermenêutica que possibilitaria analisar os limites e as fraquezas de determinadas abordagens da crítica literária do tempo de Orpheu e daquela praticada no momento em que o autor se encontra à frente da página literária de República.

Guiando-se pelo seu caderno de recortes, além de transcrever recensões críticas e notas de jornais portugueses acerca da revista Orpheu, e fazer comentários sobre esses textos, entre 31 de dezembro de 1960 e 11 de Maio de 1962, Alfredo Guisado “[...] proferiu ontem [18 de Fevereiro de 1970] na Livraria Quadrante, evocativa do grupo Orfeu" uma palestra "a 


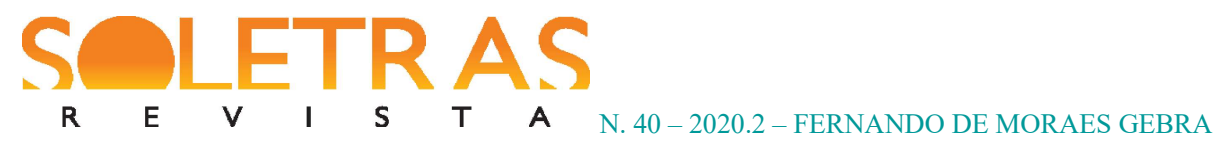

propósito do seu recente livro Tempo de Orfeu” (REPÚBLICA, 19 fev. 1970, p. 1). Reportada na primeira e na nona páginas em um artigo sem assinatura e intitulado "Alfredo Guisado falou do Orfeu", o articulista assim resume as palavras do autor que recém publicara seu livro Tempo de Orfeu, reedição dos poemários Elogio da Paisagem (1915), As Treze Baladas das Mãos Frias (1916), Mais Alto (1917) e Anfora (1918).

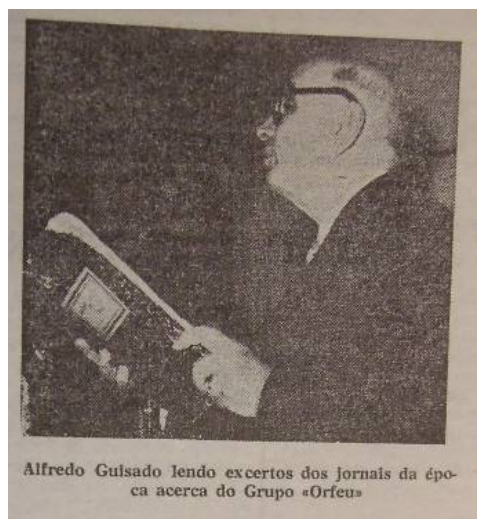

Fig.2 Alfredo Guisado com seu caderno de recortes "Críticas do Orfeu", na Livraria Quadrante, em Lisboa. Fonte: Jornal República, 19 fev. 1970, p. 9

[...] Contou entre outros casos e acontecimentos, onde se reuniam, o motivo porque foi escolhido o "Irmãos Unidos" para o local dessas reuniões, o modo como nesse Restaurante nasceram Álvaro de Campos, e a mencionada revista, e, por fim referiu-se à forma como a Imprensa da época a recebeu, lendo algumas curiosas críticas que a atacaram, não esquecendo de relatar como o nome da revista foi escolhido, o que sucedeu após a sua publicação, com casos sensacionais como por exemplo o assalto ao citado Restaurante por um grupo de caceteiros que se propunha espancar os componentes do grupo que ali todas as noites se reuniam, etc.

Referiu-se também às acusações que lhe fizeram os alienistas da época, consultados pela Imprensa acerca do que pensavam dos colaboradores de Orpheu, lendo a opinião dos professores Egas Moniz e Júlio de Matos, a maneira chocarreira como os jornais humoristas de então satirizaram, e, enfim, o ataque permanente e cerrado como a mesma revista e os seus colaboradores e, sobretudo os seus fundadores, sofreram durante demoradas semanas, pois os aludidos jornais foram unânimes em declarar que tudo aquilo não passava de uma brincadeira que ninguém suportaria e que nada ficaria, o que o tempo se incumbiu de desmentir, visto que ainda hoje os malucos daquela época estão presentes no íntimo dos que na Poesia se têm evidenciado... (REPÚBLICA, 19 fev. 1970, p. 9) 
Os textos que viriam a compor o livro O Orpheu por Dentro apresentam um hibridismo genológico, pois há elementos do ensaio, da crônica e de reflexões memorialísticas. Trata-se, pois, de um conjunto significado de textos acerca da gestação, publicação e recepção crítica da revista Orpheu, bem como do alcance e significado da produção artística de cada membro dessa geração. A partir de um corpus de textos de Alfredo Guisado publicados no jornal República e que incidem nas transcrições de textos da imprensa portuguesa e comentários acerca das atitudes dos jornalistas da época, examino, neste artigo, a atitude responsiva de Guisado a enunciados tanto dos textos de imprensa de 1915 como daqueles publicados na década de 1960, durante a gestação e organização de dados que comporiam o livro de memórias projetado.

\section{A crítica da crítica: dialogismo em processo}

Conforme Mikhail Bakhtin, todo discurso constrói-se em vista do outro, numa atitude responsiva, uma vez que se espera a resposta desse outro. Em qualquer enunciado, é possível encontrar pelo menos duas vozes em relação de tensão ou de complementariedade, numa “interação viva e tensa” (BAKHTIN, 2010, p. 88). O dialogismo interno é, pois, condição inerente da linguagem, uma vez que todo discurso apresenta relações contratuais ou polêmicas com discursos anteriores. As relações dialógicas "são possíveis não apenas entre enunciações integrais (relativamente), mas [...] a qualquer parte significante do enunciado [...] se ouvirmos nela a voz do outro" (BAKHTIN, 2015b, p. 210).

O discurso de outrem - o dos jornais que classificaram os artistas de Orpheu como paranoicos ou como mistificadores, e o da crítica do tempo da escrita dos artigos de Guisado, certamente representada por João Gaspar Simões - passa, quando incorporado na estrutura concreto-semântica dos muitos textos estampados em República, a servir aos propósitos do autor que o enuncia. Dessa forma, os textos de imprensa de Alfredo Guisado incorporam na sua filigrana discursiva discursos de outrem, tanto para os confirmar como para os refutar. No caso em exame, essas enunciações alheias são desconstruídas no interior do discurso do 


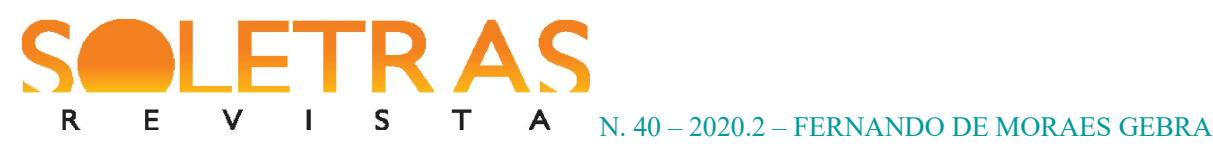

diretor da página literária de República, como fica explícito em texto precisamente intitulado “Crítica literária”, e datado de 13 de outubro de 1961.

Se, como se tem provado, os poemas do Pessoa e do Sá Carneiro valem o que, efectivamente, valem, como se entende que se escrevesse o que se escreveu a respeito deles, nessa longínqua data? Como se compreende que as "Odes", de Álvaro de Campos, fossem como foram de tal modo ridicularizadas e bem assim os versos de Sá-Carneiro e os seus nomes achincalhados em longos e repetidos artigos dos jornais de todo o País, quando, afinal, se chega à conclusão de serem qualquer coisa de notável? Quem estava no certo - apetece perguntar - eram esses senhores "críticos" de então ou os que "marcam" actualmente, entre os quais se encontram alguns que, na actualidade, por a Imprensa tanto os ter incensado, chegarem a convencer-se de que, na verdade, sabem o que vem a ser a crítica literária e, por isso, sabem o que dizem? (GUISADO, 13 out. 1961, p. 4)

As unidades linguísticas "ridicularizadas", "achincalhados" pertencem a enunciados dos "senhores 'críticos' de então", isto é, daquela "longínqua data", enquanto "qualquer coisa de notável” faz referência às aferições dos que “"marcam' actualmente” o panorama cultural português. É digno de nota o uso das aspas em "críticos" e "marcam", possibilitando que se tragam para o interior do enunciado de Alfredo Guisado discursos daqueles que legitimavam, respectivamente, as atitudes críticas daqueles que achincalharam os de Orpheu ("críticos") e dos que se consideravam donos absolutos da verdade "por a Imprensa tanto os ter incensado" (“marcam"). Dessa forma, os discursos dos legitimadores dos críticos de então e dos do tempo de enunciação de Guisado são refutados no interior do seu discurso.

Quem tinha ou tem razão? Chega a parecer impossível que tudo aquilo se tivesse dito e admitido em jornais de bastante categoria da nossa terra. Como o caso se passou há muitos anos, os velhos o podiam ter esquecido e os novos o não conheciam, é que resolvi publicar aquelas "engraçadas" opiniões, a fim de se fazer uma ideia do que vale em Portugal a tal tão discutida crítica literária (GUISADO, 13 out. 1961, p. 4). 
Fica, pois, explícito o motivo da transcrição das “"engraçadas' opiniões”: desqualificar a crítica literária em Portugal, tanto naquele período em que muitos dos jornais escreveram textos jocosos acerca das produções literárias insertas em Orpheu, como no tempo da enunciação, em que determinados críticos, como Gaspar Simões, emitiam juízos como bem lhes aprouvesse. No texto de 31 de dezembro de 1960, "O caso do Orpheu (I)", apresenta-se uma dialogicidade a estabelecer uma relação polêmica com o discurso de "[...] alguns artigos que, na data do aparecimento daquela revista, se publicaram na Imprensa, no nosso país" (GUISADO, 31 dez. 1960, p. 7); no de 10 de novembro de 1961, “Continuando...", a tonalidade jocosa volta-se aos " "críticos' do momento que atravessamos".

Alguns amigos e vários leitores têm-me dito que seria interessante continuar a transcrever o que diziam os jornais da época a respeito do Orfeu, agora que, segundo os "críticos" do momento que atravessamos, aquela revista e uns quantos colaboradores, que do grupo também faziam parte, devem ser considerados como das altas figuras da nossa Literatura (GUISADO, 10 nov. 1961, p. 5).

Note-se o uso da expressão "uns quantos colaboradores", a se referir à atitude dos “"críticos' do momento que atravessamos", pois estes restringiram ao estatuto do cânone literário autores como Fernando Pessoa e Mário de Sá-Carneiro e relegaram ao esquecimento os demais membros da geração de Orpheu. No caso específico do uso que esses referidos críticos faziam do nome de Fernando Pessoa, elevando-o com o intuito de legitimarem as opiniões do autor de Mensagem, canonizando-o nas historiografias literárias, para posteriormente publicarem as cartas que Pessoa lhes escrevera elogiando as obras, constitui o que Alfredo Guisado chama de "reclame". Essa linha de raciocínio, ao desmascarar as intenções de críticos como João Gaspar Simões, encontra-se nos seguintes textos: “Comentário” (17 de agosto de 1943), “A confissão de Lúcio, por Mário de Sá-Carneiro” (31 de julho 1946) e "Não me enganei" (13 de setembro 1963). No texto precisamente intitulado “Crítica literária”, de 13 de outubro de 1961, escreve Guisado acerca "desses indivíduos"; 


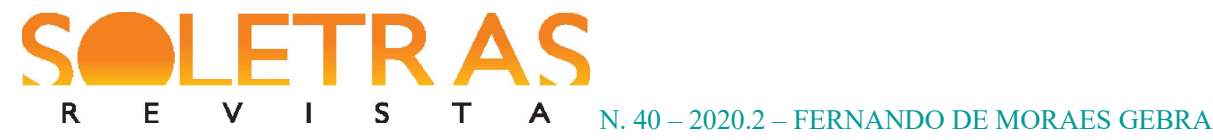

Convém avisar o público que uma grande parte desses indivíduos tem por fim escrever trabalhos literários sobre os mencionados poetas ou sobre a revista em causa, no intuito da venda garantida que encontra no mercado. É sempre, com enorme interesse, que esses trabalhos literários são recebidos, porque se convencem os leitores de que tendem a elucidá-los, quando, afinal, na sua maioria, contendo verdadeiras histórias que podem ser consideradas como das da Carochinha, induzem em erros quem as adquira (GUISADO, 13 out.1961, p. 4).

Trata-se de uma das ideias mais reiteradas por Alfredo Guisado nos seus textos, pois constitui o princípio motivador da escrita do livro O Orpheu por Dentro, uma vez que o autor considerava que apenas os três sobreviventes do grupo estariam autorizados a escrever o que se passou naquela época, e não os ensaístas e biográficos que, segundo ele, optavam por inventar acontecimentos apenas com o intuito de venda garantida de edições acerca de Fernando Pessoa, de Sá-Carneiro e da revista Orpheu. É intuito de Alfredo Guisado desfazer equívocos e avisar o público incauto acerca do que ele mesmo chama de "histórias que podem ser consideradas como das da Carochinha", como também se evidencia no texto "Ainda as críticas do Orpheu", no qual se evidencia o projeto editorial de Alfredo Guisado de transformar os textos publicados na década de 1960 na sua página literária de República no livro O Orpheu por Dentro.

Continuo nestas transcrições porque assim mo pediram se bem que, esta e outras, virão mais tarde no volume que se publicará brevemente com o título de O Orpheu por dentro, volume que elucidará, convenientemente, os leitores acerca do que foi aquela famosa revista, o que em volta dela se passou, etc., com o fim de acabar com uma grande série de notícias com que vários pretendem explicar o que eles a si próprios não explicam porque não sabem (GUISADO, 29 dez. 1961, p. 5).

Os artigos de 1915 transcritos por Alfredo Guisado na sua página literária de República, ao constituir um discurso alheio e citado, passa, conforme metodologia proposta por Mikhail Bakhtin, a servir aos propósitos do discurso citante, perceptível em seu último parágrafo do texto "As críticas do Orpheu”, de 15 de dezembro de 1961, com os enunciados interrogativos visando aos "padres-mestres críticos e ensaístas actuais" e comparando-os aos 
"críticos de então". Até que ponto uns e outros são da mesma igualha? Assinado por pseudônimo, Crispim, o artigo publicado em A Nação em 15 de abril de 1915 encontra-se na página 21 do caderno de recortes de Alfredo Guisado.

Que dizem a isto os padres-mestres críticos e ensaístas actuais? São eles ou os daquele tempo que têm razão? Ou são tão bons uns como os outros? Por que não criticam os críticos de então já que não é fácil que os críticos de então os possam criticar? (GUISADO, 15 dez. 1961, p. 5).

Da mesma forma que se refere ao discurso do articulista que se ocultava sob o pseudônimo de Crispim, em A Nação, como uma "prosa chocarreira", Alfredo Guisado também desmascara as intenções irónicas de outro jornalista que assinou dois artigos com o pseudónimo Dr. X. Em “O Orpheu e a crítica”, de 5 de janeiro de 1962, escreve Guisado: “O 'Dr. X' em causa - quem diabo seria este crítico? - ia fingindo que elogiava para mais ridicularizar o Orpheu e os seus colaboradores" (GUISADO, 5 jan. 1962, p. 5). Seguindo o mesmo procedimento argumentativo do texto de 15 de dezembro de 1961, no de 1962, após a transcrição do texto do Dr. X, Guisado compara os críticos daquele momento aos do tempo da enunciação: "Como não percebia, fingia que elogiava. Agora o caso mudou de figura: grande número daqueles que elogiam, fingem que percebem" (GUISADO, 5 jan. 1962, p. 5).

$\mathrm{O}$ procedimento estilístico da antítese demonstra, na estrutura superficial do enunciado, uma diferença entre os "os críticos daquele momento" e os do tempo da enunciação, entretanto, a construção discursiva com os verbos "elogiar" e "perceber", precedidos ou não do verbo "fingir" - "não percebia" (críticos daquele momento) e "grande número daqueles que elogiam" (críticos do tempo da enunciação), e "fingia que elogiava" (primeiro caso) e "fingem que percebem" (segundo caso) - permite perceber o ponto em comum entre os dois tipos de críticos: ausência de saberes necessários ao exercícios de sua atividade crítica. Ao trocar de posição o verbo "fingir", Alfredo Guisado pretende estabelecer um efeito de sentido de ironia, revelando que, por trás das aparentes diferenças de concepção, os críticos de então e os do seu tempo são desprovidos do saber que os qualificaria para a atividade analítico-interpretativa. 


\section{Paranoia ou mistificação na Capital}

Como comentado anteriormente, em 31 de dezembro de 1960, Alfredo Guisado inicia as transcrições dos textos de imprensa colados no seu caderno. Na primeira página do caderno, encontra-se "Literatura de manicómio", publicado em A Capital, em 30 de março de 1915, “[...] um artigo verdadeiramente assassino, dando o mote para a longuíssima série de diatribes que iriam ser lançadas pela Imprensa sobre o Orpheu” (BLANCO, 2016, p. 83).

Como o famoso caso do Orpheu é assunto que, no campo literário, no momento presente tem interesse, transcrever-se-ão para estas colunas alguns artigos que, na data do aparecimento daquela revista, se publicaram na Imprensa, no nosso país. Assim, escrevia então A Capital, jornal da tarde, que era muito lido em Lisboa (GUISADO, 31 dez. 1960, p. 7).

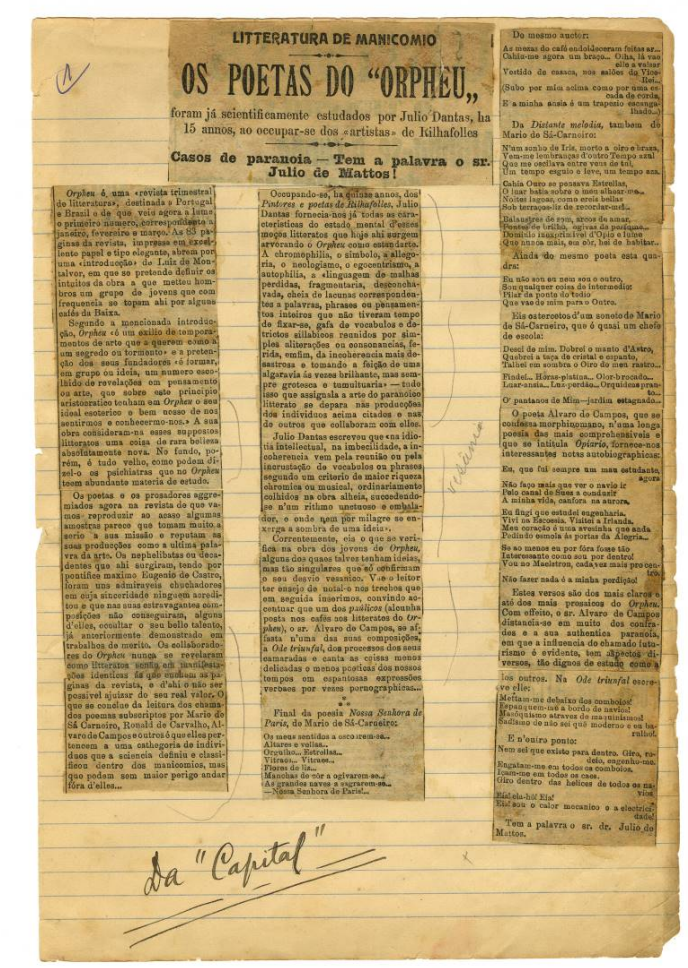

Fig.3 Recortes do jornal A Capital (30 de março de 1915), incluído no caderno "Críticas de Orfeu". Fonte: Coleção Fernando Távora, Acervo Fundação Engenheiro Marques da Silva, Col-1-Lote 07.14-0001 
A experiência de Alfredo Guisado com o gênero jornalístico fê-lo, muitas vezes, iniciar a sua argumentação a partir de um diálogo com o leitor, guiando-o, neste caso, para o extenso título do artigo de A Capital, qual seja "Literatura de Manicómio" - Os poetas do Orpheu foram já cientificamente estudados por Júlio Dantas, há 15 anos, ao ocupar-se dos “artistas" de Rilhafoles. - Casos de paranoia - Tem a palavra o Sr. Júlio de Matos”. O memorialista opta por guiar o leitor por esses textos naquela altura já tão distantes: “Ora façam o favor de ler primeiro os títulos do artigo. [...] Agora, a seguir, se transcreve uma parte do mesmo artigo que foi publicado a três colunas no referido jornal e na primeira página" (GUISADO, 31 dez. 1960, p. 7).

No artigo "Continuando...", de 10 de novembro de 1961, Alfredo Guisado transcreve novamente esse artigo de $A$ Capital. No longo título desse artigo, aparece a palavra "artistas" entre aspas. Na época em que Orpheu foi publicada, os experimentos estilísticos das artes das vanguardas europeias eram considerados sintomas de patologias mentais. Psiquiatras como Júlio de Matos entendiam as maiúsculas alegorizantes, a linguagem fragmentada, o intenso cromatismo, as frases com reticências como expedientes que diagnosticavam a paranoia e eram encontrados nos internos do Hospital Psiquiátrico Miguel Bombarda, antigo Hospital de Rilhafoles. Entendia-se esse tipo de produção como sintomas de patologias que eram classificadas, com exaustão taxionômica.

Na mesma diretriz pragmática do artigo de $A$ Capital, embora com nuances de humor e paródia, publicaram-se, no jornal A Luta, em 11 de abril de 1915, duas entrevistas na rubrica intitulada "Arte Exótica. Os poetas do Orfeu e os alienistas. Dois ilustres psiquiatras portugueses, um dos quais o sr. Dr. Julio de Matos, dão a sua opinião sobre o "paúlismo'”. Na página 19 do caderno de recortes, encontra-se a de Júlio de Matos, transcrita no texto "Os psiquiatras e o Orpheu", de 30 de junho de 1961, enquanto na página anterior, transcrita em "Ainda os alienistas e os poetas do Orfeu", de 22 de setembro de 1961, a de um psiquiatra que não quis ser identificado, mas que Alfredo Guisado, no tempo da enunciação do seu texto, afirma a certeza de se tratar de Egas Moniz: "Ora, segundo depois se averiguou, o ilustre entrevistado era o prof. Dr. Egas Moniz” (GUISADO, 30 jun. 1961, p. 5).

O primeiro entrevistado, Júlio de Matos, ao tratar do poema "16", de Sá-Carneiro uma das produções da revista que mais incomodou os críticos, junto com "Ode Triunfal" e "Opiário", de Álvaro de Campos - embora encontre a problematização da "dissociação da 
personalidade" (apud GUISADO, 30 jun. 1961, p. 5), entende esse fenômeno a partir de uma ótica limitada. Júlio de Matos não consegue entender os procedimentos linguísticos como forma de representação da crise que se instaura no sujeito pois se guia por preceitos de uma psiquiatria positivista.

O entrevistado não considera os de Orpheu malucos, antes julga-os simuladores, pois identifica neles apenas um objetivo de escandalizar o burguês. Compara as atitudes dos jovens poetas de Orpheu com anedotas envolvendo Charles Baudelaire. Seu juízo é deveras taxativo: "Os do Orpheu são apenas simuladores. É evidente que quem quiser ser extravagante tem de se assemelhar aos loucos. O terreno comum onde se encontram é o disparate" (apud GUISADO, 30 jun. 1961, p. 5).

O segundo entrevistado, certamente Egas Moniz, refere-se aos de Orpheu como "meninos sem talento", "chuchadores' de mau gosto", que teriam que ser trancafiados em Rilhafoles na ala dos dementes.

São meninos sem talento que querem chamar sobre si as atenções do público vomitando asneiras. Uns copiam detestavelmente Eugénio de Castro, na sua fase do Oaristos, outros plagiam, horrivelmente, alguns poemas do Só. Há um nóvel poeta que publica um soneto sem pontuação alguma. É a sua originalidade. E todos fazem um simbolismo idiota e grotesco, sem elevação nem critério. Pergunta-me se são produções de degenerados. Nada disso. Esses escreveriam melhor. Querem chamar sobre si o escândalo, mas nem isso conseguem. Repare nos nomes: Carneiro, Guisado. Um mau "carneiro" pessimamente "guisado". Intolerável (GUISADO, 22 set. 1961, p. 5).

As duas entrevistas com os dois alienistas ocupam duas páginas do caderno de recortes de Alfredo Guisado, o que faz com que ele transcreva cada uma em uma data, dado o pouco espaço de que dispunha na sua página literária. $\mathrm{Na}$ introdução ao primeiro desses dois textos, escreve Alfredo Guisado:

Vejamos o que disseram os psiquiatras acerca dos do Orpheu, depois de ter saído o primeiro número daquela revista em março de 1915. Começaremos pelo prof. Dr. Júlio de Matos que foi entrevistado pelo jornal A Lucta, de que era director o dr. Brito Camacho (GUISADO, 30 jun. 1961, p. 5). 
Houve um longo intervalo entre uma e outra transcrição de partes de um mesmo texto. Na sua página literária, então intitulada "República das Letras", Alfredo Guisado costumava escrever de duas a três recensões críticas dos livros que iam sendo lançados no mercado editorial português enfeixadas sob o título "O que já saiu”, uma secção intitulada "O que vai sair", com brevíssimas notas sobre publicações próximas de serem lançadas, e ainda um poema de algum escritor ou até mesmo de sua própria autoria. Não havia, pois, muito espaço para longas transcrições, sobretudo esse texto de $A$ Luta, o que faz com que o autor anuncie: “Mas há mais. Transcreveremos qualquer dia" (GUISADO, 30 jun. 1961, p. 5).

Considerando a efemeridade do veículo de publicação periódica - " [...] onde tudo acaba tão depressa [...]", uma vez que "[...] se compra num dia e no dia seguinte é usada para embrulhar um par de sapatos ou forrar o chão da cozinha" (CANDIDO, 1992, p. 14), Alfredo Guisado inicia o texto de 22 de setembro com um parágrafo introdutório que situa novamente o leitor no contexto daquelas transcrições.

Publicámos, há algumas semanas, a entrevista que, em 1915, determinado redactor de $A$ Luta, o jornal então dirigido pelo Dr. Brito Camacho, teve com o prof. Dr. Júlio de Matos acerca dos poetas do Orfeu. Hoje transcrevemos a opinião de outro alienista notável, opinião confiada ao mesmo redactor daquele antigo diário. É o seguinte: (GUISADO, 22 set. 1961, p. 5).

O "mesmo redactor daquele antigo diário", na ocasião, transcreveu o penúltimo parágrafo da introdução do primeiro número de Orpheu, escrita por Luís de Montalvor, afirmando ser esse texto escrito "numa linguagem rasteira e desconexa" (GUISADO, 22 set. 1961, p. 5). Embora até hoje haja críticos que referendam esse posicionamento, partilho do que escreve Dionísio Vila Maior, segundo o qual a introdução de Montalvor marca o "cultivo da excepcão e da diferença" (1996, p. 79).

A introdução de Luís de Montalvor (1971, p. 11-12) separa de si o discurso de outrem, à medida em que se negam os seguintes sintagmas: "O que é propriamente revista em sua essência de vida e quotidiano" e "outros meios, maneiras de realizar arte". O primeiro 
sintagma é negado pela expressão "deixa-o de ser Orpheu”, referindo-se aos tipos comuns de se fazer revista em essência e cotidiano; já o segundo pela expressão "se desassemelhar", referindo-se aos outros meios de produzir arte.

Ao fazer um retrato do grupo como seres eleitos e selecionados, em diálogo uns com os outros, como se vê nos sintagmas "em seleção", "raros e interiores", "procura estética de permutas", Montalvor demonstra também a busca de um "público leitor de selecção", que tenha "refinados propósitos em arte". O culto da Beleza com maiúscula, tão ao gosto das estéticas finisseculares, alia-se ao exílio como fenômeno geracional: "Puras e raras suas intenções como seu destino de Beleza é o do: - Exílio!”. Em seguida, afirma: "Bem propriamente, Orpheu é um exílio de temperamentos de arte que a querem como a um segredo ou tormento...".

Além de aferir juízo crítico totalmente desfavorável à introdução de Montalvor, o anônimo articulista de $A$ Luta, em tom jocoso, transcreve trechos dos seguintes poemas: primeiro terceto de "Sonho egípcio", de Alfredo Guisado (1971, p. 60), os dois primeiros versos da quarta estrofe de "Distante melodia", de Mário de Sá-Carneiro (1971, p. 20), a vigésima segunda estrofe e os dois primeiros versos da vigésima terceira de "Opiário", de Álvaro de Campos (1971, p. 96-97) e fragmentos de "Ode Triunfal” (1971, p. 105-106).

Uff! Afinal o Orfeu é uma amálgama desarmoniosa de despautérios. Não merece a pena ver mais. Vamos até à janela. A tarde é calma e no "Oriente, ao oriente do Oriente", num céu em que "Iris dorme meu Ser em cortinados lassos", definem-se manchas vagas "em portos de alquimia", como eles dizem. Mas o doutor manda-nos chamar. Damo-nos pressa em interrogá-lo: (apud GUISADO, 22 set. 1961, p. 5).

Os excertos citados entre aspas referem-se, de maneira paródica, respectivamente, ao quarto verso da segunda estrofe de "Opiário", de Álvaro de Campos (1971, p. 93), ao último verso de "Pagão", de Alfredo Guisado, e ao quarto verso da terceira estrofe de "Ângulo", de Sá-Carneiro. Nesse parágrafo do texto do redator do jornal A Luta, incorpora-se o discurso de outrem - o dos então jovens poetas de Orpheu - por meio da paródia, isto é, o redator usa sintagmas de poemas de Álvaro de Campos, Alfredo Guisado e Sá-Carneiro para construir um 
parágrafo paródico, isto é, que vai numa direção diametralmente oposta aos discursos poéticos desses autores, depreciando a simbologia dos sintagmas utilizados e tratando-os como se fossem parte de um projeto de se fazer "um simbolismo idiota e grotesco, sem elevação nem critério" (apud GUISADO, 22 set. 1961, p. 5).

O discurso de outrem - o dos colaboradores de Orpheu - passa, pois, a servir aos propósitos dos enunciados dos jornalistas que tanto se valeram da paródia para apoucarem a produção poética dos de Orpheu, tal como ocorre no artigo A crítica furiosa”, publicada em 9 de abril de 1915 em O Jornal, arquivado na página 5 do caderno de recortes de Guisado. Transcrito em "Prosseguindo", de 8 de dezembro de 1961, esse artigo parece preocupar-se em demasia com o poema “16”, de Mário de Sá-Carneiro (1971, p. 18-19), sobretudo a penúltima estrofe:

As mesas do Café endoideceram feitas ar...

Caiu-me agora um braço... Olha, lá vai ele a valsar

Vestido de casaca, nos salões do Vice-Rei... (1971, p. 19)

O redator constrói uma paródia, ao criar uma micronarrativa com suposições de que "o braço foi para lá praticar irreverências", vestido "apenas de casaca", mas certamente repreendido, o que o fará também colocar um par de calças. Alfredo Guisado aproveita-se desse discurso paródico da casaca e das calças para apoucar "certos críticos que eu conheço" que, na época de Orpheu, nem calças nem casaca usavam, pois ainda estavam na fase do bibe e do calção: "Como os leitores vêem, já naquele tempo a crítica era deste gênero e se sujeitava a ser ridicularizada. O que faria se existissem certos críticos que eu conheço e que então ainda não tinham nascido ou andavam de bibe e calção" (GUISADO, 8 dez. 1961, p. 5).

\section{Entre blagues e cafés: $O$ Mundo da imprensa lisboeta}

Se houve vozes que assinalavam a produção literária contida em Orpheu como sintomas de alienação mental, houve outras que consideravam aqueles rapazes irreverentes. Ao não tomarem a sério as produções órficas por não encontrarem nelas outro sentido que não 


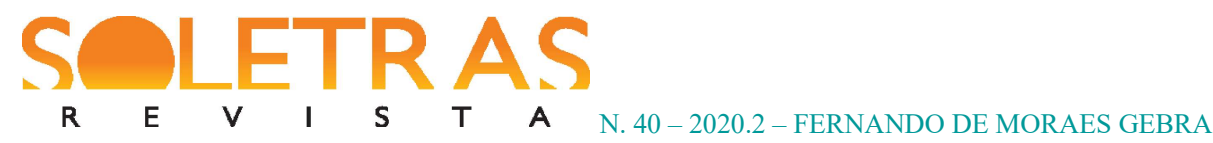

fosse o de irritar e escandalizar o gosto burguês, muitos jornalistas responderam aos vários discursos órficos com sátiras incisivas, paródias chocarreiras e até mesmo insultos disfarçados de piadas. É o caso, por exemplo, da gazetilha "Orfeu", assinada por Antunes Belo e publicada em 11 de abril de 1915 em O Jornal; a crônica-carta "Orpheu nos infernos. Do noivo ao futuro sogro", um "folhetim" publicado em A Capital, em 14 de abril de 1915; a crônica humorística “As portas do Parnaso. Os bardos do Orfeu são doidos com juízo. Para Rilhafoles?! Não! Para a mão de vaca dos 'Irmãos Unidos'”, assinado por um pseudónimo apresentado como Dr. X, e publicada em 8 de abril de 1915.

Arquivado na página 17 do caderno de recortes de Alfredo Guisado, o poema satírico “Orfeu”, assinado por António Antunes Belo, foi publicado na seção "Gazetilha” em O Jornal no dia 11 de abril de 1915, e republicado no texto "A imprensa e o Orpheu" (GUISADO, 13 abr. 1962, p. 5).

Admiro toda a arte complicada

Dos paúlicos poetas do Orfeu.

Admiro-a e porque não percebo nada

- E nem eles percebem mais do que eu.

A Arte é tudo! - É Deus o Universo:

Tudo o que a mente sonha é ainda a Arte.

Como há-de, pois, caber num curto verso

Isso que é "toda a gente e toda a parte"?

Justificam-se assim versos imensos

De trinta sílabas e até de mais.

E compreendo que ainda os torne densos

A compreensão de vazios ideais.

Não vos preocupeis com formas belas

Poetas confusos de "ideais futuros".

- Deus fez a noite p'r'á encher de estrelas

E cria as rosas sobre os vis monturos!

Mas sempre o dia segue à escuridão

E o que era trevas fica iluminado;

- Dai-nos, pois noutro Orfeu a tradução

Do que trazia o número passado. 


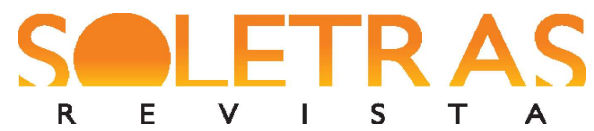

Gênero humorístico muito comum em verso, a gazetilha serve a vários propósitos de escárnio. No caso em exame, ao servir-se de um enunciado alheio - "toda a gente e toda a parte", trecho do último verso do poema "Ode Triunfal", de Álvaro de Campos - o enunciador desse poema faz com que esse enunciado alheio sirva aos propósitos do seu discurso, isto é, afirmar uma arte poética contrária à produção literária dos de Orpheu. Nesse sentido, o pluralismo tão bem expresso na lamentação final do poema de Campos - "Ah não ser eu toda a gente e toda a parte!” é reduzido pelo autor da gazetilha a “[...] versos imensos? De trinta sílabas e até mais".

Por um lado, está a arte que o autor, que assina com o pseudônimo António Antunes Belo, considera bela, a arte das "formas belas", comparada às "estrelas" e às "rosas", por outra, a que ele quer combater, isto é, a "[...] arte complicada / Dos paúlicos poetas do Orfeu”, comparada à noite - no sentido de escuridão e dificuldade de se ver com claridade, enfatizando o que ele acredita ser uma arte hermética - e aos monturos - no sentido de charco, emitindo, pelo uso dessa palavra, a depreciação dessa poesia que ele reconhece não compreender. Esse poema satírico funciona como uma orientação aos "poetas confusos de 'ideais futuros"” para que, segundo ele, saibam separar o joio do trigo, isto é, a noite (escuro, impenetrável) das estrelas (claridade, compreensão), as rosas dos monturos. Ao relacionar noite com estrelas e rosa a monturos, o enunciador parece mostrar duas faces do que ele acredita ser a poesia em Portugal na altura, como se ambas convivessem no mesmo espaço. Nova orientação sarcástica surge na última estrofe, quando se retoma a ideia da primeira estrofe, acerca do que ele considera incompreensibilidade da poesia de Orpheu, não apenas para os seus leitores como também para os próprios artistas daquela revista.

No texto “A imprensa e o Orpheu”, de 27 de abril de 1962, Guisado transcreve “Orpheu nos infernos. Do noivo ao futuro sogro. Folhetim de A Capital, 15-4-1915”, assinado por Guedes de Oliveira e arquivado na página 20 do referido caderno de recortes. Curiosamente, "Opiário", que tantos sentidos engendra para a compreensão do mal estar português embrenhado de atmosfera decadentista, só foi percebido por Guedes de Oliveira na questão laboral, engendrando um texto humorístico no qual também se veem mazelas da sociedade portuguesa da época, "deste lusismo fatal, sentimental, dolorido e lacrimoso, em que cada um chora com muitíssima razão as suas desditas e o cruel e triste mal de não ter nascido aposentado e com o ordenado por inteiro" (apud GUISADO, 27 abr. 1962, p. 4).

SOLETRAS - Revista do Programa de Pós-Graduação em Letras e Linguística - PPLIN

Faculdade de Formação de Professores da UERJ

Número 40 (jul.-dez. 2020) - ISSN: 2316-8838

DOI: https://doi.org/10.12957/soletras.2020.51438 


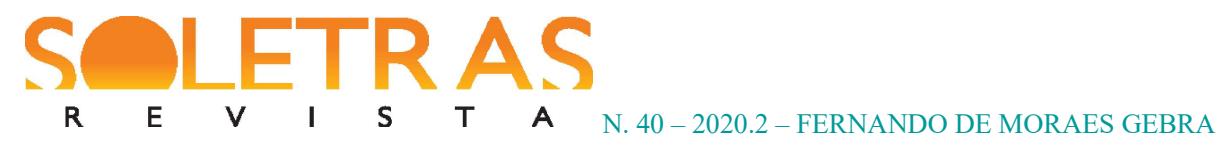

Assinado por pseudônimo, Dr. X, o artigo publicado em $O$ Mundo em 8 de abril de 1915 encontra-se nas páginas 14 e 15 do caderno de recortes de Alfredo Guisado. O texto "Às Portas do Parnaso - Os Bardos do Orpheu são doidos com juízo - Para Rilhafoles?! Não! Para a mão de vaca dos "Irmãos Unidos"” apresenta duas partes nitidamente separadas pelo sinal matemático de conclusão (três pontos a formarem um triângulo). A primeira dessas partes é toda transcrita em 29 de dezembro de 1961. Ao transcrever a segunda parte do artigo em 5 de janeiro de 1962, Alfredo Guisado finaliza o conteúdo que está colado na página 14 do caderno de recortes. Em “A crítica e o Orpheu”, de 2 de fevereiro de 1962, transcreve todo o conteúdo da página 15.

Toda a tese da terceira parte desse texto assinado por Dr. X consiste em encontrar uma categoria na qual todas as produções da revista seriam enquadradas, por isso o termo "Odes Triunfais" como sinônimo das produções dos de Orpheu. Nessa linha de raciocínio, confundese o triunfalismo de uma poética visceral das sensações fundidas à civilização da máquina, presente na "Ode Triunfal", de Álvaro de Campos, com a atmosfera decadentista-simbolista de poemas como "Opiário", do primeiro Álvaro de Campos, antes de ele ter conhecido Alberto Caeiro, como explica Fernando Pessoa na célebre carta a Adolfo Casais Monteiro: "E assim fiz o Opiário, em que tentei dar todas as tendências latentes do Álvaro de Campos, conforme haviam de ser depois reveladas, mas sem haver ainda qualquer traço de contacto com o seu mestre Caeiro" (PESSOA, 1999b, p. 344).

Como se percebe, os jornais de 1915 englobavam as produções literárias dos órficos na mesma categoria de "Odes Triunfais" ou até mesmo de futuristas. É também de Fernando Pessoa - ao assumir na imprensa lisboeta o drama em gente heteronímico na máquina de escrever de Álvaro de Campos -, a distinção entre o Interseccionismo ainda com elementos do Paúlismo - evolução das poéticas finisseculares, notadamente o Decadentismo e o Simbolismo - e o Futurismo, este último com traços apenas do "[...] assunto que me inspirou, não pela realização [...]” (PESSOA, 1999a, p. 166). Em carta de 4 de junho de 1915, dirigida do director do Diário de Notícias, escreve o autor da "Ode Triunfal":

A atitude principal do futurismo é a Objectividade Absoluta, a eliminação, da arte, de tudo quanto é alma, quanto é sentimento, emoção, lirismo, subjectividade em suma. $\mathrm{O}$ futurismo é dinâmico e analítico por excelência. 
Ora se há coisa que [seja] típica do Interseccionismo (tal é o nome do movimento português) é a subjectividade excessiva, a síntese levada ao máximo, o exagero da atitude estática. "Drama estático", mesmo, se intitula uma peça, inserta no $1 .^{\circ}$ número do Orpheu, do sr. Fernando Pessoa. E o tédio, o sonho, a abstracção são as atitudes usuais dos poetas meus colegas naquela brilhante revista.

A César o que é de César. Aos Interseccionistas, chame-se interseccionistas. Ou chame-se-lhes paúlicos, se se quiser. Esse termo, ao menos, caracterizaos, distinguindo-os de outra qualquer escola. Englobar os colaboradores do Orpheu no futurismo é nem sequer saber dizer disparates, o que é lamentabilíssimo (PESSOA, 1999a, p. 166).

A despeito do tom jocoso com que o Dr. X escreve "Às portas do Parnaso" com o intuito de ridicularizar as produções estampadas nas páginas da revista Orpheu, o seu discurso apresenta particulares que convém examinar. Em atitude condenatória das poéticas que seguem a tradição decadentista-simbolista, muito presente em Orpheu - "os vapores de uma exótica literatura que lhes tem dado volta ao miolo" -, o articulista defende um ideal de arte que expresse a realidade tal como ela é percebida pelos sentidos. Assim, orienta-se o seu discurso paródico, com o intuito humorístico de "explicar as diferenças de inspiração e energia encontradas nas páginas exóticas do Orfeu" (apud GUISADO, 2 fev. 1962, p. 5).

São chamados à baila os cafés Martinho da Arcada, os Irmãos Unidos e o Montanha, cada um com uma peculiaridade: "Na triste mansidão do 'Montanha', na atmosfera suculentamente culinária dos 'Dois Irmãos Unidos' ou na febril e nervosa agitação do 'Martinho' é que eles compõem as suas 'Odes Triunfais"” (apud GUISADO, 2 fev. 1962, p. 5). O primeiro apresenta uma "febril e nervosa agitação", uma vez que até hoje se encontra situado na Praça do Comércio, lugar de grande afluência de pessoas, a ponto de algumas das manifestações políticas se passarem por lá, como se vê em “é do 'Martinho' em noite de manifestação". Já o segundo, na sua "triste mansidão", teria, segundo o anônimo, inspirado a atmosfera sinestésica do poema "Nossa Senhora de Paris", de Sá-Carneiro. E, por fim, "na atmosfera suculentamente culinária dos 'Dois Irmãos Unidos"”, “aquele pavimento superior da sala do popular restaurante tem o quer que seja de barco a conduzir a alma, não para o canal de Suez, mas para a Praça da Figueira" (apud GUISADO, 2 fev. 1962, p. 5). Como se vê, o articulista apresenta uma visão estreita da arte, como se ela tivesse que se ancorar na 


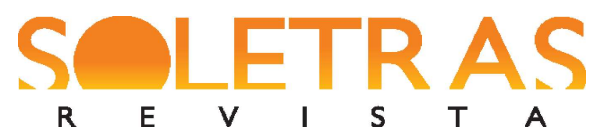

realidade tangível e não perscrutar camadas inconscientes com associações imprevistas, tocando esferas para além do cotidiano.

Ao apontar as incoerências dos críticos daquela época, finalizando o texto com uma comparação entre os críticos de 1915 e os do momento da enunciação do seu texto "quarenta e sete anos depois" - Alfredo Guisado insiste no propósito do livro O Orpheu por Dentro, qual seja o de estabelecer o que realmente se passou naquele contexto. Outrossim, o autor, ao transcrever um texto que o mesmo jornal $O$ Mundo publicara 27 de março de 1915 trata-se da primeira recensão crítica a Orpheu, que fora posta à venda no dia anterior, uma sexta-feira, 26 de março - quer ressaltar uma mudança de opinião do referido periódico.

Orfeu, revista trimestral de literatura: Um grupo de novos escritores, acaba de lançar uma revista trimestral Orfeu, que é uma espécie de resumo das várias correntes modernas na nossa literatura. Mesmo que se não concorde com a orientação geral dos colaboradores da nova revista, tem de se lhes reconhecer talento e iniciativa, coisas, infelizmente, raras entre nós, sobretudo em assuntos destes. O primeiro número de $\mathrm{Orfeu}$, que temos sobre a nossa mesa, contém variada colaboração das mais características figuras de entre os novos. Inclui versos de Mário de Sá-Carneiro, Ronald de Carvalho, Alfredo Pedro Guisado e Côrtes-Rodrigues e insere duas poesias futuristas (as primeiras, cremos, que aparecem entre nós) do malogrado Álvaro de Campos. Em prosa, além da esquisita introdução de Luís de Montalvor, director da revista, há um drama num acto de Fernando Pessoa. A capa de Orfeu, do lápis de José Pacheco, é curiosíssima (apud GUISADO, 2 fev. 1962, p. 5).

$\mathrm{Na}$ nota de 27 de março, expressões como "resumo de várias correntes modernas na nossa literatura", "tem de se lhes reconhecer talento e iniciativa" são elogiosas em relação a Orpheu. A concessiva "Mesmo que se não concorde com a orientação geral dos colaboradores da nova revista" precede o reconhecimento de seus talentos e iniciativas. O também anônimo autor dessa nota ainda destaca que talento e iniciativa são "coisas, infelizmente, raras entre nós", sobretudo no que se refere às letras e às artes. É bem possível que Guisado entenda a contradição no jornal $O$ Mundo, pois o texto de 27 de março parece exaltar as qualidades dos jovens literatos, enquanto o de 8 de abril utiliza uma verve sarcástica para banalizar suas produções como arremedos de inspirações meramente cotidianas dos ambientes dos cafés da Baixa lisboeta. 


\section{Considerações finais}

Conforme José Blanco, foi A Capital, com o artigo "Literatura de manicómio", no qual se transcrevem palavras de Júlio de Matos, e publicado em 30 de março daquele ano, que deu "[...] mote para a longuíssima série de diatribes" (BLANCO, 2015, p. 83). Talvez tenha sido essa a razão pela qual outros jornalistas tenham se empolgado em repisar o senso comum da crítica de então aos poetas de Orpheu, que os situava entre a paranoia e a mistificação, entre a loucura rilhafolesca e as blagues dos cafés lisboetas, conforme explica Alfredo Guisado nos seus textos de República, nos quais, ao transcrever na íntegra textos da imprensa portuguesa de 1915, opera neles uma verdadeira desmontagem dos seus argumentos, realizando, pois, a crítica da crítica.

Dos muitos textos de imprensa que figurariam no projetado livro O Orpheu por Dentro e que teria como subtítulo história de uma revista literária, dezoito deles incidem diretamente nos textos que a imprensa portuguesa publicou acerca da revista Orpheu e de seus protagonistas. Alfredo Guisado transcreveu-os e comentou-os na sua página literária entre 31 de dezembro de 1960 e 11 de maio de 1962, guiando-se pelo seu caderno de recortes que foi utilizado também para uma conferência ministrada em 18 de fevereiro de 1970 na Livraria Quadrante, por ocasião da reedição dos seus poemários Elogio da Paisagem (1915), As Treze Baladas das Mãos Frias (1916), Mais Alto (1917) e Anfora (1918), enfeixados sob o significativo título de Tempo de Orfeu.

Nem todos os textos arquivados no caderno de recortes de Alfredo Guisado foram transcritos na sua página literária de República, entretanto, um deles, "Literatura de manicómio", de A Capital, aparece em dois textos, "O caso do Orpheu (I)", de 31 de dezembro de 1960, e “Continuando...”, de 10 de Novembro de 1961, além de já ter sido transcrito em partes na década de 1940, precisamente no "Comentário", de 26 de março de 1943. Essa reiteração nas transcrições de textos que já tinham sido publicados na imprensa portuguesa em 1915, principalmente o conhecido "Literatura de manicómio", talvez se deva pelo fato de o autor estar consciente - como já várias vezes manifestara a respeito da sua coluna - do suporte jornal, com espaço deveras limitado. 


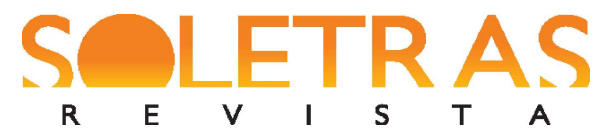

Determinados textos que fazem elogios aos de Orpheu não foram transcritos ou mencionados na página literária de Alfredo Guisado, como os que foram publicados nos periódicos El Tea de Puentarêas, O Jornal e Alma Nova de Faro. O único texto transcrito por Guisado e que faz referências positivas a Orpheu é a "Crónica Literária", de Fernando Pessoa, portanto, de um membro do grupo. Se o objetivo de Alfredo Guisado era documentar a história literária da revista e de tudo o que ao redor dela se passou, por que transcreveu apenas os juízos críticos contrários às propostas inovadoras dos membros da geração de Orpheu?

Percebe-se, nessa atitude de seleção dos textos de seu caderno de recortes para publicação nas páginas de República, um projeto de organização em livro, algumas vezes até mesmo explicitado aquando das transcrições. Outrossim, é possível detectar uma dupla intenção de Alfredo Guisado ao reproduzir nas páginas da República os textos dos jornais da época de Orpheu: por um lado, documentar a história da revista e da geração literária, por outro, mostrar que a incompreensão dos críticos de então era semelhante à dos críticos da Presença, como Gaspar Simões. Embora esses elogiassem a produção de alguns dos de Orpheu, "fingem que percebem" (GUISADO, 5 jan 1962, p. 5) o significado daqueles versos. Guisado desqualifica, pois, no interior do seu discurso, os críticos de então e os críticos vigentes na década de 1960.

Nos textos de imprensa de Alfredo Guisado acerca de Orpheu, principalmente naqueles que foram examinados no presente artigo, centrado nas transcrições dos recortes de jornal arquivados no seu caderno, o memorialista seleciona a partir de outro meio - o seu caderno de recortes - o que será dado a público novamente anos depois de ter cuidadosamente colecionado o que a imprensa ia publicando acerca da "revista que tanto deu o que falar" (GUISADO, 11 out. 1963, p. 5). Dessa forma, guia o leitor por esse intricado labirinto de discursos que respondem uns aos outros.

\section{Referências}

ALFREDO GUISADO FALOU DO ORPHEU. República, Lisboa, p. 1 e 9, 19 fev. 1970.

BAKHTIN, Mikhail. Questões de literatura e de estética: a teoria do romance. Trad. A. F. Bernardini et al. $6^{\text {a }}$ ed. São Paulo: Hucitec, 2010. 


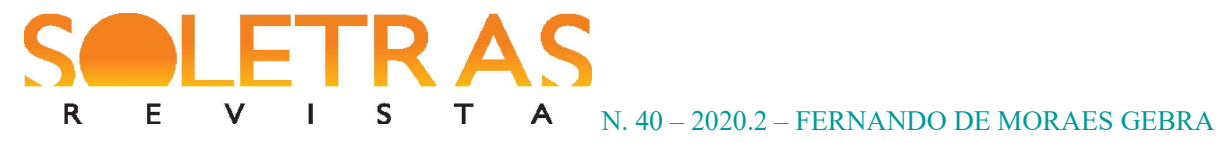

BAKHTIN, Mikhail. Os gêneros do discurso. Estética da criação verbal. Trad. P. Bezerra. São Paulo: Martins Fontes, 2015a. p. 261-306.

BAKTHIN, Mikhail. Problemas da poética de Dostoiévski. Trad. direta do russo, notas e prefácio de Paulo Bezerra. $5^{\mathrm{a}}$ ed. Rio de Janeiro: Forense Universitária, 2015b.

BLANCO, José. Orpheu Regabofe Tiroliro. MAIOR, Dionísio Vila \& RITA, Annabela. 100Orpheu. Viseu: Edições Esgotadas, 2016, p. 81-95.

CANDIDO, Antonio. A vida ao rés-do-chão. CANDIDO, Antonio et al. A crônica: o gênero, sua fixação e suas transformações no Brasil. Rio de Janeiro: Casa Rui Barbosa, 1992.

GUISADO, Alfredo. A crítica e o Orpheu. República, Lisboa, p. 5, 2 fev. 1962.

GUISADO, Alfredo. A imprensa e o Orpheu. República, Lisboa, p. 5, 13 abr. 1962.

GUISADO, Alfredo. A imprensa e o Orpheu. República, Lisboa, p. 4, 27 abr. 1962.

GUISADO, Alfredo. Ainda as críticas do Orpheu. República, Lisboa, p. 5, 29 dez. 1961.

GUISADO, Alfredo. Ainda os alienistas e os poetas do Orfeu. República, Lisboa, p. 5, 22 set. 1961.

GUISADO, Alfredo. As críticas do Orpheu. República, Lisboa, p. 5, 15 dez. 1961.

GUISADO, Alfredo. Comentário. República, Lisboa, p. 3,12 mar. 1943.

GUISADO, Alfredo. Comentário. República, Lisboa, p. 7, 18 jul. 1943.

GUISADO, Alfredo. Continuando... República, Lisboa, p. 5, 10 nov. 1961.

GUISADO, Alfredo. Crítica literária. República, Lisboa, p. 4, 13 out. 1961.

GUISADO, Alfredo. Não exagero. República, Lisboa, p. 5, 11 out. 1962.

GUISADO, Alfredo. O caso do Orpheu - I. República, Lisboa, p. 7, 31 dez. 1960.

GUISADO, Alfredo. O Orpheu e a crítica. República, Lisboa, p. 5, 5 jan. 1962.

GUISADO, Alfredo. Os psiquiatras e o Orpheu. República, Lisboa, p. 5, 30 jun. 1961.

GUISADO, Alfredo. Prosseguindo. República, Lisboa, p. 5, 8 dez. 1961.

GUISADO, Alfredo. Um episódio. República, Lisboa 5, 29 out. 1960.

SOLETRAS - Revista do Programa de Pós-Graduação em Letras e Linguística - PPLIN

Faculdade de Formação de Professores da UERJ

Número 40 (jul.-dez. 2020) - ISSN: 2316-8838

DOI: https://doi.org/10.12957/soletras.2020.51438 


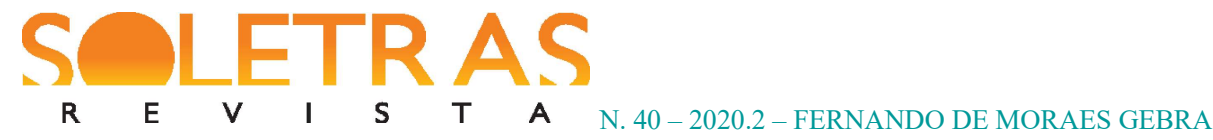

MAIOR, Dionísio Vila. Introdução ao modernismo. Coimbra: Almedina, 1996.

ORPHEU: revista trimestral de literatura. $4^{\mathrm{a}}$ reed. Lisboa: Ática, 1971, v.1.

PESSOA, Fernando. Correspondência: 1905-1922. Org. Manuela Parreira da Silva. São Paulo: Cia. Letras, 1999a.

PESSOA, Fernando. Correspondência: 1923-1935. Org. Manuela Parreira da Silva. Lisboa: Assírio \& Alvim, 1999b.

SILVA, Patrícia. Alfredo Guisado and the Orpheu Affair: Tracing the Magazine's Reception and Impact through the Távora Archive, Pessoa Plural - A Journal of Fernando Pessoa Studies, Special Issue: New Insights into Portuguese Modernism from the Fernando Távora Collection, 12, 2017. p. 288-332.

SIMÕES, João Gaspar. Vida e obra de Fernando Pessoa. História duma geração. $5^{\mathrm{a}}$ ed. Lisboa: Dom Quixote, 1987.

\title{
Orpheu and the press in Alfredo Guisado's notebook: "Cuttings" of a literary maganize
}

\begin{abstract}
Alfredo Guisado (1891-1975) set up a notebook with cuttings of press reviews about Orpheu magazine in 1915. Many of these texts collected and filed on the notebook were published and commented by Alfredo Guisado on his literary page on the paper República, mainly in the 1960s. The present paper analyses these texts in which 1915 cuttings of press are mentioned and transcribed. The literary criticism, known as a discourse genre, responds to previous enunciates, establishing an alive and tense relation with them, according to Mikhail Bakhtin. I analyze the struggle among three enunciations: a) the Portuguese press' discourse about the reception of Orpheu in 1915; b) the presencists' discourse, understood, as a discourse of the other inside Alfredo Guisado's enunciations in the 1960s; c) Guisado's discourse, featured by ironies, veiled controversy and even open controversy. The Author had, thereby, as a goal to respond to discourse attitudes from Presença magazine's members, who spread in Portuguese literary environment the idea about which they would have been Orpheu's great publishers.
\end{abstract}

Keywords: Orpheu. Alfredo Guisado. República. Literary criticism. Cuttings of press.

Recebido em: 02 de junho de 2020.

Aceito em: 10 de julho de 2020. 